\title{
CYTO-DEPRESSIVE POTENTIAL OF GANODERMA LUCIDUM, PLEUROTUS OSTREATUS, AND THEIR BINARY COMBINATIONS AGAINST MERISTEMATIC CELLS OF ALLIUM CEPA L.
}

\author{
MOYEN UDDIN PK PK, $^{1,2}$ \\ ${ }^{1}$ Research Fellow, Institute of Biological Science, Rajshahi University, Rajshahi, Bangladesh, ${ }^{2}$ Department of Biochemistry, Independent \\ University of Bangladesh, Dhaka, Bangladesh, ${ }^{3}$ Department of Biochemistry, Primeasia University, Dhaka, Bangladesh. \\ Email: biomoyen@gmail.com \\ Received: 16 August 2018, Revised and Accepted: 29 October 2018
}

ABSTRACT

Objective: The current study is designed to evaluate the cyto-depressive effects of Ganoderma lucidum (GL) and Pleurotus ostreatus (PO) and their binary amalgams (GL+PO) on meristematic cells of Allium cepa L.

Methods: Experiments were assessed by utilizing A. cepa bioassay.

Results: Onion knobs were exposed to $500 \mu \mathrm{g} / \mathrm{mL}, 1000 \mu \mathrm{g} / \mathrm{mL}$, and $2000 \mu \mathrm{g} / \mathrm{mL}$ groupings of the concentrates for naturally visible and minute examination. The concentrates essentially repressed the root development of $A$. cepa L. contrasted with the control in a period of treatment and concentration-dependent manner $(\mathrm{p}<0.05)$. In addition, photomicrographs revealed chromosomal aberrations extending from c-mitosis, stickiness, and bridges in the root tip meristematic cells of $A$. cepa. All mushroom extracts demonstrated remarkable cyto-depressive impacts on meristematic cells of A. cepa L. with some changeability.

Conclusion: In view of the results come out, GL and PO could be considered as potential sources of anticancer mixes. Notwithstanding, additionally thinks about are essential for disengagement and portrayal of the bioactive mixes and more examination on their pharmacological properties is required. It is first report in Bangladesh where we studied cyto-depressive role of edible mushrooms, Ganoderma lucidum (GL) and Pleurotus ostreatus (PO).

Keywords: Mitosis inhibition, Chromosome aberration, Mitotic index, Hydromethanolic extract, Anticancer.

(C) 2019 The Authors. Published by Innovare Academic Sciences Pvt Ltd. This is an open access article under the CC BY license (http://creativecommons. org/licenses/by/4. 0/) DOI: http://dx.doi.org/10.22159/ajpcr.2019.v12i2.29124

\section{INTRODUCTION}

Ganoderma lucidum (GL), which is commonly called as "Reishii" in Bangladesh, shows various pharmacological effects, namely antioxidative, antitumor, and antiviral [1-4]. González-Palma et al. have been shown that the fruiting bodies of Pleurotus ostreatus (PO) have exhibited signal antioxidant activity [5].

Recently, we have found that a numerous higher and medicinal plants have exerted antimitotic effects in vivo and in vitro assays, and these findings authenticated based on their content of potential mutagenic substances [6-8]. Few studies have been carried out including cytodepressive of mushrooms [9] and no record found on cyto-depressive study on the binary combination of GL and PO.

In this study, we have evaluated the binary combinations of GL and PO for its cytotoxic effects on Allium cepa L. root tip meristematic cells at different concentrations of mushroom extracts. This is the first report in Bangladesh where the cyto-depressive activity of GL, PO, and their binary combinations was reported.

\section{METHODS}

Mushrooms collection and preparation of extracts

Edible mushrooms, GL and PO, were collected from Mushroom Development Institute belong to the Department of Agriculture Extension, Ministry of Agriculture, Bangladesh, Savar, Dhaka-1340. Mushrooms were identified and authenticated by Research officer from Mushroom Development Institute, Bangladesh. About $250 \mathrm{~g}$ of powder of each mushroom was shocked in $80 \%$ methanol and was kept at $25^{\circ} \mathrm{C}$ for 7 days in the shade. Fractions were collected, concentrated, and dried and were stored in the refrigerator for future uses.

\section{Dose preparation}

The hydromethanolic extracts of GL, PO, and their combinations were used to screen cyto-depressive effects with three different concentrations, namely 500, 1000, and $2000 \mu \mathrm{g} / \mathrm{ml}$, for A. cepa assay. Copper sulfate (PubChem CID: 24463) was used as a standard compound in Allium cepa test. At room temperature, the $A$. cepa bulbs were grown in tap water.

\section{Sample application}

After 3-4 days, when the roots were $2-5 \mathrm{~cm}$ in length, the bulbs were treated with mushrooms extract, copper sulfate, and distilled water. Total 195 onions comprising 2-5 cm root length were used in this experiment for $24,48,72,96$, and $120 \mathrm{~h}$ of consecutive treatments. Group 1: Used $9 \times 5$ onions for the treating with positive control $(\mathrm{C}+)$, 500,1000 , and $2000 \mu \mathrm{g} / \mathrm{ml}$, Group 2: Used $3 \times 5$ onions for negative control (C-), $2000 \mu \mathrm{l}$, Group 3: Used $9 \times 5$ onions for GL, 500, 1000, and $2000 \mu \mathrm{g} / \mathrm{ml}$, Group 4: Used $9 \times 5$ onions for PO, 500, 1000, and $2000 \mu \mathrm{g} / \mathrm{ml}$, and Group 5: Used $9 \times 5$ onions for GL+PO, 500, 1000, and $2000 \mu \mathrm{g} / \mathrm{ml}$. Solutions of each treatment were changed with appropriate concentrations $(500,1000$, and $2000 \mu \mathrm{g} / \mathrm{ml})$.

\section{Pre-treatment}

Root tips from every treatment were gathered and settled in a solution of acidic acid and alcohol (Carnoy's fixative; 1:3 of acidic acid and ethanol). After specific treatment, knobs from each group were protected in $70 \%$ alcohol. In the wake of washing the root tips (utilizing refined water), root knobs were hydrolyzed with $1 \mathrm{~N} \mathrm{HCl}$ at $65^{\circ} \mathrm{C}$ for $5 \mathrm{~min}$, and after that, bulbs were washed once more.

\section{Slides preparation}

Around 1-2 mm of the bulbs were cut and set on the 10 slides for every treatment. Thereafter observing root length enlargement for each 
group, $2000 \mu \mathrm{g} / \mathrm{ml}$ concentration-treated groups were chosen for slide arrangement since at this dosage (after $48 \mathrm{~h}$ ), no root development was watched. At last, root tip was submerged in aceto-orcein and kept for $3 \mathrm{~min}$ and, at that point, compressed the root tips utilizing the metal pole. Afterward, $50 \mu \mathrm{l}$ of aceto-orcein was included for appropriate recoloring of cell core.

\section{Microscopic observations}

Slides were seen under a light magnifying instrument at $\times 400$ to see clear picture of the chromosome deviations and least 100 cells for every slide were counted (Nine slides watched every treatment). The mitotic index (MI) was learned by detaching the amount of cells in mitosis with the total number of cells [10]. All analyses in this examination were completed in triplicate.

\section{Statistical analysis}

GraphPad Prism 6 (Pad Software, Inc., USA) was used to analyze data, and results are expressed as mean \pm standard deviation. Error bars were expressed as $95 \%$ CI. p $<0.05$ was measured to specify statistical significance connotation.

\section{RESULTS}

\section{MI calculation}

Table 1 shows MI, which is the measure of cytotoxicity in all living organisms. The level of cytological effects can be calculated by assessing the decreased rate of MI. The MI of mushroom extracts was concentration-dependent manner and the lowest MI value was found at $2000 \mu \mathrm{g} / \mathrm{ml}$ treated with mushrooms and standard compound. The MI for GL+PO extract declined significantly $(\mathrm{p}<0.001)$ from $500 \mu \mathrm{g} / \mathrm{ml}$ to $2000 \mu \mathrm{g} / \mathrm{ml}$. The MI values were $0.126,0.177$, and 0.240 , respectively,

Table 1: Mitotic index of control and different treatments

\begin{tabular}{lllll}
\hline \multicolumn{2}{l}{ Treatments } & $\begin{array}{l}\text { Total } \\
\text { cells } \pm \text { SE }\end{array}$ & $\begin{array}{l}\text { Dividing } \\
\text { cells } \pm \text { SE }\end{array}$ & $\begin{array}{l}\text { Mitotic } \\
\text { index } \pm \text { SE }\end{array}$ \\
\hline $\mathrm{C}+$ & $500 \mu \mathrm{g} / \mathrm{ml}$ & $1022 \pm 9.31$ & $236 \pm 9.22$ & $0.230 \pm 2.00^{\#}$ \\
& $1000 \mu \mathrm{g} / \mathrm{ml}$ & $1139 \pm 10.71$ & $254 \pm 10.01$ & $0.223 \pm 1.08^{\#}$ \\
& $2000 \mu \mathrm{g} / \mathrm{ml}$ & $1105 \pm 7.90$ & $158 \pm 11.34$ & $0.142 \pm 1.47^{* *}$ \\
$\mathrm{C}-$ & $2000 \mu \mathrm{l}$ & $1239 \pm 12.34$ & $463 \pm 7.89$ & $0.372 \pm 1.91$ \\
$\mathrm{GL}$ & $500 \mu \mathrm{g} / \mathrm{ml}$ & $987 \pm 15.11$ & $184 \pm 9.00$ & $0.187 \pm 2.03^{*}$ \\
& $1000 \mu \mathrm{g} / \mathrm{ml}$ & $1046 \pm 14.33$ & $190 \pm 7.19$ & $0.182 \pm 1.48^{*}$ \\
& $2000 \mu \mathrm{g} / \mathrm{ml}$ & $1158 \pm 17.91$ & $205 \pm 8.02$ & $0.177 \pm 2.74^{*}$ \\
$\mathrm{PO}$ & $500 \mu \mathrm{g} / \mathrm{ml}$ & $976 \pm 9.03$ & $262 \pm 12.11$ & $0.268 \pm 2.00$ \\
& $1000 \mu \mathrm{g} / \mathrm{ml}$ & $1028 \pm 10.02$ & $256 \pm 15.01$ & $0.249 \pm 2.01$ \\
& $2000 \mu \mathrm{g} / \mathrm{ml}$ & $1035 \pm 8.27$ & $249 \pm 13.70$ & $0.240 \pm 1.46$ \\
$\mathrm{GL}+\mathrm{PO}$ & $500 \mu \mathrm{g} / \mathrm{ml}$ & $1065 \pm 11.30$ & $158 \pm 7.02$ & $0.149 \pm 1.46^{*}$ \\
& $1000 \mu \mathrm{g} / \mathrm{ml}$ & $1133 \pm 12.72$ & $155 \pm 9.02$ & $0.137 \pm 2.01^{*}$ \\
& $2000 \mu \mathrm{g} / \mathrm{ml}$ & $1089 \pm 9.23$ & $138 \pm 6.02$ & $0.126 \pm 1.09^{* *}$ \\
\hline
\end{tabular}

$\mathrm{C}+$ : Positive control $\left(\mathrm{CuSO}_{4}\right), \mathrm{C}-$ : Negative control (distilled water),

GL: Ganoderma lucidum, PO: Pleurotus ostreatus, GL+PO: Binary combination.

Three fields were counted for calculating a total number of cells. Nine slides for each treatment $\times 100$ cell in each slide. ${ }^{*} \mathrm{p}<0.05,{ }^{* *} \mathrm{p}<0.01$ (treatments vs. distilled water), "Non-significant for $\mathrm{GL}+\mathrm{PO}, \mathrm{GL}$, and PO at a concentration of $2000 \mu \mathrm{g} / \mathrm{ml}$, whereas the MI value of positive control ( $\mathrm{C}+$ ) and distilled water $(\mathrm{C}-$ ) was calculated with 0.142 and 0.372 at the same concentration. The column statistics of MI of control and treatments are shown in Table 2. Column statistics explicate that cytological effects of mushrooms on root tips of $A$. серa depend on the concentrations of the sample $(p<0.05)$.

\section{Chromosome aberrations analysis}

Chromosome aberrations and incidences of chromosome aberrations encouraged by the treatment of mushrooms extract (Fig. 1) and obtained data revealed that the frequencies of chromosomal aberrations were increased with dose-dependent treatments. At $2000 \mu \mathrm{g} / \mathrm{ml}$, stickiness, bridges, and c-mitosis of the chromosome were the most common aberrations observed (Fig. 1a-d). The stickiness of chromosome was found to be the most frequent aberration obtained for all treatments. The total percentage of chromosomal aberration of $\mathrm{C}+$ was calculated with $4.34 \%$ while $4.14 \%, 3.47 \%$, and $5.14 \%$ were found, respectively, for GL, PO, and GL+PO at a concentration of $2000 \mu \mathrm{g} / \mathrm{ml}$ (Fig. 1e).

\section{Physicochemical analysis}

Table 3 shows that mushroom extracts exhibit significant inhibition of A. cepa roots tip growth in compared to negative and positive control. The cyto-depressive effects of treatments depend on the increasing concentration of mushrooms extract and duration of each treatment. The average root lengths of negative control $(2000 \mu \mathrm{l})$ and positive control $(2000 \mu \mathrm{g} / \mathrm{ml})$ were $2.71 \mathrm{~cm}$ and $3.01 \mathrm{~cm}$, respectively, at day 0 of treatment. After $48 \mathrm{~h}$ of treatment, root length was increased by negative control with $44.58 \%$ and positive control with $3.5 \%$, whereas GL with $7.6 \%$, PO with $3.62 \%$, and $2.86 \%$ for binary combination of GL and PO were found correspondingly. Subsequent treatment of A. cepa root tip with $72 \mathrm{~h}$ or more, increasing of root length was terminated by positive control and GL+PO ( $<<0.05)$. From Fig. 2, survival of the meristematic root cells was affected by concentrations and durations of treatment. Meristematic cells division was terminated by mushrooms at $2000 \mu \mathrm{g} / \mathrm{ml}, 1000 \mu \mathrm{g} / \mathrm{ml}$, and $500 \mu \mathrm{g} / \mathrm{ml}$, respectively, after $72 \mathrm{~h}$, $96 \mathrm{~h}$, and $120 \mathrm{~h}$ correspondingly. During termination of cell divisions, A. cepa roots color was changed to brownish from white appearance of roots. Results are shown in Fig. 2a-d.

\section{DISCUSSION}

Here, we studied cytological effects of edible mushrooms at a defined concentration of mushroom extracts on fast-growing cells (A. cepa root tip) as like of cancer cells, and these were evaluated by analyzing root growth and root morphology. The higher concentration of treatments exhibited an inhibition of root length, and the result obtained was statistically significant differences when compared with negative control. Cytotoxicity was determined by detecting chromosomal aberrations as like stickiness, bridges, c-mitosis, micronucleus, and MI. The MI of A. cepa roots tip treated with $2000 \mu \mathrm{g} / \mathrm{ml}$ of GL+PO was reduced significantly in comparison to negative control $(0.126 \%$ for $\mathrm{GL}+\mathrm{PO}$ and $0.372 \%$ for negative control) while significant inhibition of root growth by copper sulfate was documented after $48 \mathrm{~h}$ of treatment $(0.142 \%$ for

Table 2: Column statistics of MI values of control and treatments

\begin{tabular}{lllll}
\hline Descriptive statistics & C- & C+ & GL & PO \\
\hline $25 \%$ & 0.349 & 0.142 & 0.177 & 0.24 \\
Median & 0.36 & 0.223 & 0.182 & 0.249 \\
$10 \%$ & 0.349 & 0.142 & 0.177 & 0.24 \\
$75 \%$ & 0.372 & 0.23 & 0.187 & 0.268 \\
$90 \%$ & 0.372 & 0.23 & 0.187 & 0.268 \\
Lower 95\% CI of mean & 0.3318 & 0.07683 & 0.1696 & 0.2168 \\
Upper 95\% CI of mean & 0.3889 & 0.3198 & 0.1944 & 0.2878 \\
Discrepancy & -0.3603 & -0.1983 & -0.182 & 0.149 \\
95\% CI of discrepancy & $0.3318-0.3889$ & $0.07682-0.3198$ & $0.1696-0.1944$ & 0.1088 \\
p value (two-tailed) & 0.0003 & 0.0197 & 0.0003 & 0.1659 \\
\hline
\end{tabular}

C+: Positive control ( $\mathrm{CuSO}_{4}$ ), C-: Negative control (distilled water), GL: Ganoderma lucidum, PO: Pleurotus ostreatus, GL+PO: Binary combination, MI: Mitotic index,

$\mathrm{CI}$ : Confidence interval 
Table 3: The average root numbers and root lengths in controls and treatment concentrations

\begin{tabular}{|c|c|c|c|c|c|c|}
\hline \multirow{2}{*}{$\begin{array}{l}\text { Concentration } \\
(\mu \mathrm{g} / \mathrm{ml})\end{array}$} & \multirow{2}{*}{$\begin{array}{l}\text { Average root } \\
(\text { mean } \pm S D)\end{array}$} & \multicolumn{5}{|c|}{ Average root lengths (mean \pm SD) } \\
\hline & & Day 0 & Day 2 & Day 3 & Day 4 & Day 5 \\
\hline \multicolumn{7}{|l|}{$\mathrm{C}+$} \\
\hline 1000 & $25.8 \pm 5.65$ & $2.98 \pm 2.76$ & $3.00 \pm 0.87$ & $3.17 \pm 0.69$ & - & - \\
\hline 2000 & $22.4 \pm 3.46$ & $3.01 \pm 1.34$ & $3.12 \pm 0.91$ & - & - & - \\
\hline \multicolumn{7}{|l|}{$\mathrm{C}-$} \\
\hline$(2000 \mu \mathrm{l})$ & $27.6 \pm 6.89$ & $2.71 \pm 2.45$ & $4.89 \pm 1.87$ & $5.11 \pm 1.22$ & $5.43 \pm 1.45$ & $5.69 \pm 1.80$ \\
\hline \multicolumn{7}{|l|}{ GL } \\
\hline 500 & $26.6 \pm 3.56$ & $2.84 \pm 1.92$ & $2.89 \pm 0.82$ & $2.96 \pm 0.72$ & $3.07 \pm 0.87$ & $3.23 \pm 0.67$ \\
\hline 1000 & $23.9 \pm 2.98$ & $3.15 \pm 4.98$ & $3.21 \pm 0.65$ & $3.42 \pm 0.66$ & $3.53 \pm 0.64$ & - \\
\hline 2000 & $29.3 \pm 5.87$ & $2.67 \pm 2.56$ & $2.89 \pm 0.93$ & - & - & - \\
\hline \multicolumn{7}{|l|}{ PO } \\
\hline 500 & $25.6 \pm 2.46$ & $2.74 \pm 1.08$ & $2.79 \pm 0.80$ & $2.83 \pm 0.84$ & $2.92 \pm 0.86$ & $3.11 \pm 0.84$ \\
\hline 1000 & $28.9 \pm 2.09$ & $3.25 \pm 4.33$ & $3.32 \pm 0.68$ & $3.56 \pm 0.57$ & $3.62 \pm 0.34$ & - \\
\hline 2000 & $24.3 \pm 4.11$ & $2.66 \pm 2.59$ & $2.76 \pm 0.91$ & $2.86 \pm 0.82$ & - & - \\
\hline \multicolumn{7}{|l|}{$\mathrm{GL}+\mathrm{PO}$} \\
\hline 1000 & $27.9 \pm 2.04$ & $3.85 \pm 3.90$ & $3.89 \pm 0.81$ & $3.94 \pm 0.87$ & - & - \\
\hline 2000 & $23.3 \pm 5.01$ & $2.37 \pm 2.05$ & $2.44 \pm 1.03$ & - & - & - \\
\hline
\end{tabular}

C+: Positive control (CuSO), C-: Negative control (distilled water), GL: Ganoderma lucidum, PO: Pleurotus ostreatus, GL+PO: Binary combination, -: Indicates no root length increased, SD Standard deviation

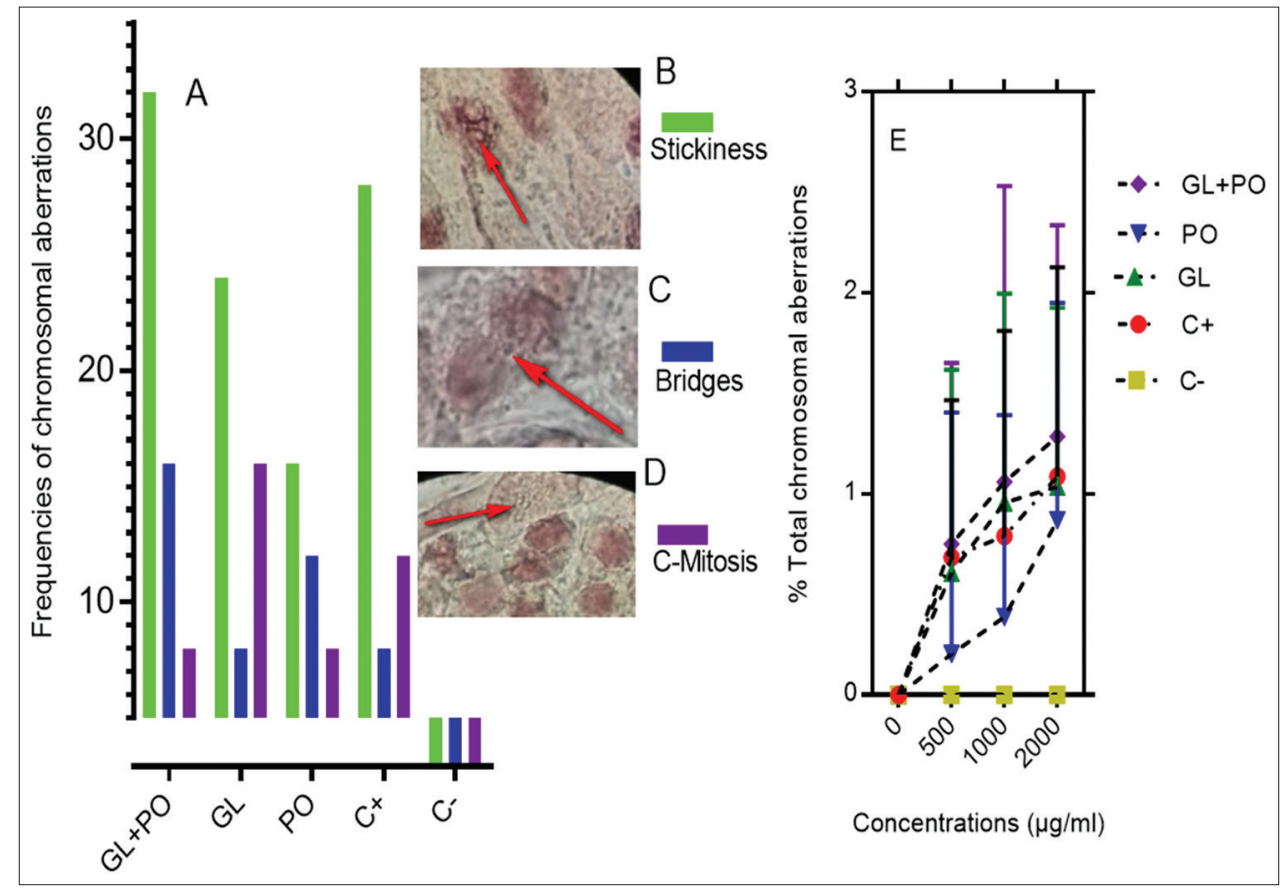

Fig. 1. Chromosomal aberrations - (a) Frequencies of chromosomal aberrations, (b) stickiness of chromosome, (c) bridges of chromosome, (d) c-mitosis, disturbance of the spindle activity, (e) percentage of the total chromosomal aberration. Three fields were totaled for computing of total number of chromosomal aberrations. Nine slides for each treatment $\times 100$ cell in each slide. ${ }^{\#} \mathrm{C}+$ positive control ( $\left.\mathrm{CuSO}_{4}\right)$, C- negative control (distilled water), GL: Ganoderma lucidum, P0: Pleurotus ostreatus, GL+P0: Binary combination

$2000 \mu \mathrm{g} / \mathrm{ml}, 0.223 \%$ for $1000 \mu \mathrm{g} / \mathrm{ml}$, and $0.230 \%$ for $500 \mu \mathrm{g} / \mathrm{ml})$. It is demonstrated that the decreased of MI below $22 \%$ in comparison to negative control can have a lethal impact on the living organisms, on the other hands declined value $<50 \%$ usually has sublethal effects, and it is called by cytotoxic limit value [11-13].

From Rojas et al., 1993, it is clear that MI measures the cellular death or delay in the cell proliferation kinetics [14] and declining in the mitotic activity could be due to termination of DNA synthesis or a hindering in the G phase of cell cycle resulting inhibiting the cell from entering mitosis [15]. In earlier, cytological effects through blocking the DNA synthesis of some herbal extracts were reported by Chen and Watkins [16] and Hoffmann et al. [17] likewise cytological effects of chemicals [18-20]. Other studies have been reported that there are several herbals inhibit mitosis as well [21]. In our studies, the decreased MI values of $A$. cepa roots tip explicate the interaction of mushrooms extract with cell DNA, resulting cell division and root growth became inhibited and also terminated at define time and concentration of treatment. Mushroom extracts, a binary combination of GL and PO, revealed the strongest mitosis inhibition effects in the root meristem cells by observing of stickiness, bridges of chromosome emphasize the premise of the toxic effects on fast-growing cells. The physicochemical properties of DNA, protein, or both have changed due to the effect of the environmental pollutants and chemical compounds causing sticky chromosome [22]. Our results presented the initiation of chromosome aberrations in the A. cepa root tip cells treated with the mushroom 


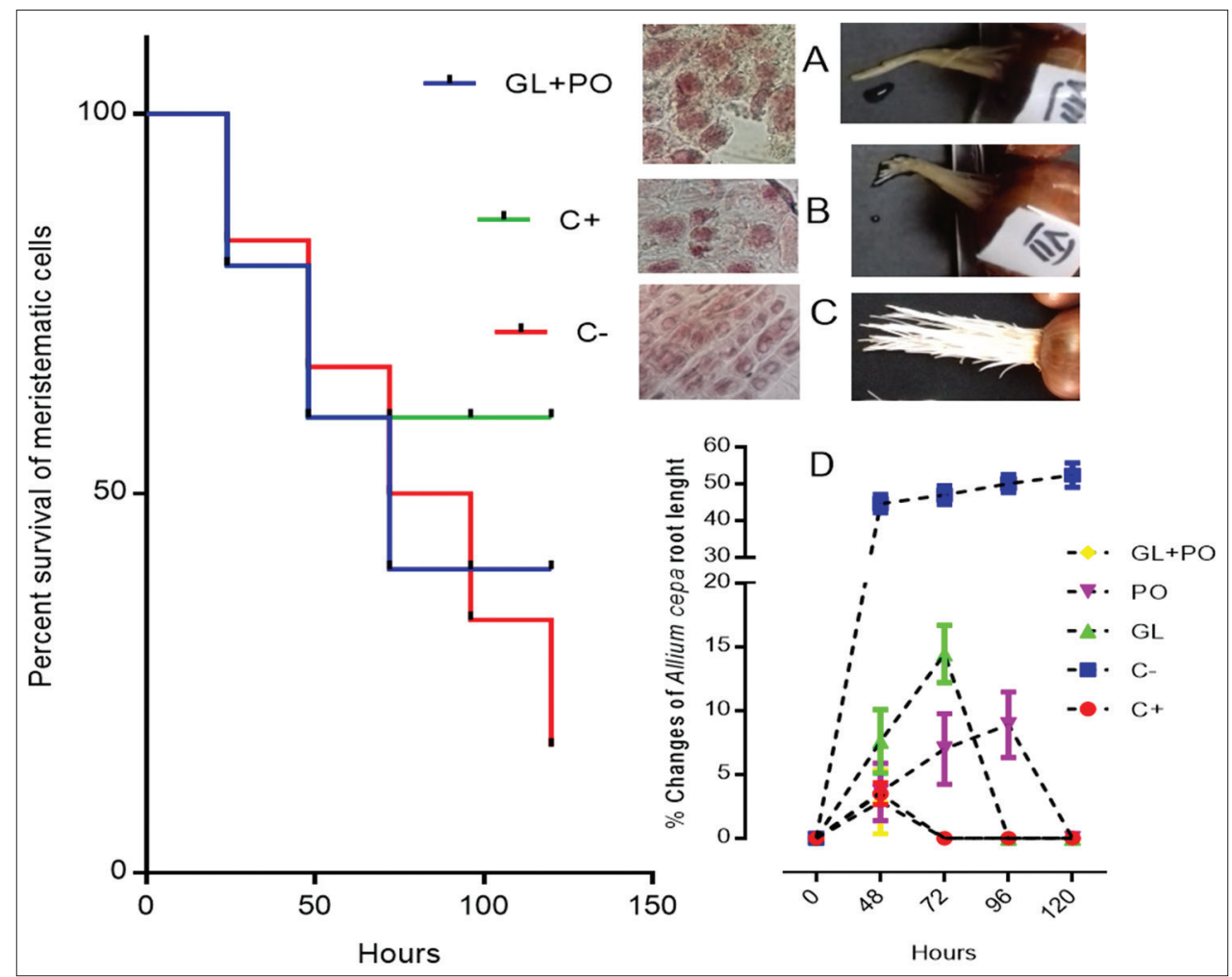

Fig. 2: Survival curve of meristematic cells (root tip cells) - (a and b) increasing of roots length was terminated by GL+PO and positive control; (c) distilled water - no effects on cell division, and (d) percent changes of Allium cepa roots length. ${ }^{*} \mathrm{C}+$ : $\mathrm{Positive}$ control (CuSO $\mathrm{H}_{4}$ ), C-: Negative control (distilled water), GL: Ganoderma lucidum, PO: Pleurotus ostreatus, GL+P0: Binary combination

extracts. Chromosome aberrations in roots tip cells increased significantly on experience to mushrooms extract, which designate mutagenic activity (Tables 1-3 and Figs. 1 and 2). These findings are relevant to the results of many scientific researches which examined the cytological effects of diverse herbal medicines [23]

\section{CONCLUSION}

The binary combinations of GL and PO extracts induced cytotoxicity (Mitosis inhibition) in A. cepa root tip meristematic cells development. Henceforward, the mix blend of GL and PO extricates is a good wellspring of medications to treat ceaseless illnesses.

\section{ACKNOWLEDGMENT}

Md. Moyen Uddin PK (MPK) is grateful to Primeasia University for providing necessary laboratory facilities for this work. The author is thankful to Rabiul Islam Talukder (RIT, Department of Biochemistry), Mohammad Sayful Islam (MSI, Department of Pharmacy), Primeasia University, Bangladesh, and Mohammad Khairul Islam Sarker, Independent University of Bangladesh, for technical and laboratory support.

\section{AUTHORS' CONTRIBUTION}

MPK conceived, designed, data analyzed, wrote original draft, and finally revised manuscript. MSI and RIT helped as volunteer researcher(s) during the period of work.

\section{CONFLICTS OF INTEREST}

The authors have declared that no competing interest exists.

FUNDING

The authors received no specific funding for this work.

\section{REFERENCES}

1. Moyen IS. In vitro doses and incubations dependent thrombolytic potential study of edible mushrooms Pleurotus ostreatus, Ganoderma lucidum and Lentinula edodes available in Bangladesh. Br J Pharm Res 2015;7:44-51

2. Islam MR, Omar M, Moyen, Mia R. Phytochemicals and antibacterial activity screening of three edible mushrooms Pleurotus ostreatus, Ganoderma lucidum and Lentinula edodes accessible in Bangladesh. Am J Biol Life Sci 2015;3:31-5.

3. Moyen IS. Antihyperglycemic activity of edible mushroom, Lentinus edodes in alloxan induced diabetic Swiss albino mice. Int J Pharm Clin Res 2014;6:121-6.

4. Tel G, Ozturk M, Duru ME, Turkoglu A. Antioxidant and anticholinesterase activities of five wild mushroom species with total bioactive contents. Pharm Biol Engl 2015;53:824-30.

5. González-Palma I, Escalona-Buendía HB, Ponce-Alquicira E, TéllezTéllez M, Gupta VK, Díaz-Godínez G, et al. Evaluation of the antioxidant activity of aqueous and methanol extracts of pleurotus ostreatus in different growth stages. Front Microbiol 2016;7:366.

6. Grant WF. Chromosome aberration assays in allium. Mutat Res Genet Toxicol 1982;99:273-91.

7. Fiskesjö G. The allium test as a standard in environmental monitoring. Hereditas 1985;102:99-112.

8. Gutfreund H. Fundamentals of enzyme kinetics. FEBS Lett 1980;116:125.

9. Rojas E, Herrera LA, Sordo M, Gonsebatt ME, Montero R, Rodríguez R, et al. Mitotic index and cell proliferation kinetics for identification of antineoplastic activity. Anticancer Drugs 1993;4:637-40.

10. Sudhakar R, Gowda KNN, Venu G. mitotic abnormalities induced by silk dyeing industry effluents in the cells of Allium cepa. Cytologia (Tokyo) 2001;66:235-9.

11. Celik TA, Aslantürk Ö. Anti-mitotic and anti-genotoxic effects of Plantago lanceolata aqueous extract on Allium cepa root tip meristem cells. Biologia (Bratisl) 2006;61:62.

12. Schulze E, Kirschner M. Microtubule dynamics in interphase cells. J Cell Biol 1986;102:1020-31.

13. Babich H. The "allium" test: A simple, eukaryote genotoxicity assay. 
Am Biol Teach 1997;59:580-3.

14. Soliman MI. Genotoxicity testing of neem plant (Azadirachta indica A. Juss.) using the Allium cepa chromosome aberration assay. J Biol Sci 2001;1:1021-7.

15. Bidau CJ, Amat AG, Yajía M, Martí DA, Riglos AG, Silvestroni A. Evaluation of the genotoxicity of aqueous extracts of ilex paraguariensis St. Hil. (Aquifoliaceae) using the allium test. Cytologia (Tokyo) 2004;69:109-17.

16. Chen L, Watkins JF. Evidence against the presence of h2 histocompatibility antigens in ehrlich ascites tumour cells. Nature 1970;225:734.

17. Hoffmann H, Kogler H, Heyse W, Matter H, Caspers M, Schummer D, et al. Discovery, Structure elucidation, and biological characterization of nannocystin, a macrocyclic myxobacterial metabolite with potent antiproliferative properties. Angew Chem Int Ed Engl Ger 2015;54:10145-8.

18. Khatri S, Phougat N, Chaudhary R, Singh B, Chhillar AK. Chemical composition, antioxidant, antibacterial and cytotoxicity analysis of Blumea lacera (burm. F.) Dc. Int J Pharm Pharm Sci 2016;8:313-9.

19. Khajapeer KV, Biswal R, Baskaran R. Evaluation of anti-cml activity of methanol and aqueous extracts of Benkara malabarica (lam.) Tirveng plant leaves. Int J Pharm Pharm Sci 2018;10:20-2.

20. Jeena K, Liju VB, Kuttan R. Antitumor and cytotoxic activity of ginger essential oil (Zingiber officinale Roscoe). Int J Pharm Pharm Sci 2015;7:341-5

21. Safarzadeh E, Shotorbani SS, Baradaran B. Herbal medicine as inducers of apoptosis in cancer treatment. Adv Pharm Bull 2014; 4 Suppl 1:421-7.

22. Lee JM, Kwon H, Jeong H, Lee JW, Lee SY, Baek SJ, et al. Inhibition of lipid peroxidation and oxidative DNA damage by Ganoderma lucidum. Phytother Res Engl 2001;15:245-9.

23. Yang Y, Wang Y, Zhan J, Shi J, Wang X, Liu G, et al. Genetic and cytological analyses of the natural variation of seed number per pod in rapeseed (Brassica napus L.). Front Plant Sci 2017;8:1890. 